\title{
Repeat midurethral sling treatment for prior midurethral sling failure
}

\author{
Chi-Feng Su $\cdot$ Kwong-Pang Tsui $\cdot$ Horng-Jyh Tsai • \\ Gin-Den Chen
}

Received: 4 February 2011 /Accepted: 18 April 2011 /Published online: 7 May 2011

(C) Springer-Verlag 2011

\begin{abstract}
We reviewed articles in the PubMed database which describe the results and outcome of a repeat midurethral synthetic sling (MUS), known as tension-free vaginal tape (TVT), or transobturator tape/tension-free vaginal tape obturator for prior MUS failure in patients who presented with persistent or recurrent stress urinary incontinence (SUI). We combined or separated the keywords "TVT," "failure," "repeat TVT," and "recurrent/ persistent SUI." The search was limited by publication data from 2000 to 2010, humans, female, and English text. A repeat TVT procedure treating prior TVT failure showed success rates ranging from $70 \%$ to $90 \%$. The outcomes showed no significant differences between a repeat retropubic route or transobturator route. A repeat MUS procedure for persistent or recurrent stress urinary incontinence is a reliable option for patients with prior MUS failure.
\end{abstract}

Keywords Midurethral sling · Repeat TVT · TVT-O · Recurrent/persistent SUI · Failure

Synopsis: Repeat midurethral sling treating recurrent or persistent stress urine incontinence reveals a good outcome.

C.-F. Su $(\varangle) \cdot$ K.-P. Tsui $\cdot$ H.-J. Tsai

Department of Obstetrics and Gynecology,

Kuang Tien General Hospital,

No.117 Sha-Tien Road Shalu District,

Taichung City 43303, Taiwan

e-mail: kurrysu@yahoo.com.tw

G.-D. Chen

Chung Shan Medical University Hospital,

Taichung, Taiwan

\section{Background}

A midurethral synthetic sling (MUS) procedure, known as tension-free vaginal tape (TVT), tension-free vaginal tape obturator (TVT-O), transobturator tape (TOT), and intravaginal slingplasty (IVS), is considered the preferred effective treatment for female stress urinary incontinence (SUI). The minimally invasive method well known as TVT was first reported by Ulmsten [1] and now includes the retropubic route and transobturator route (TVT-O or TOT). It has shown a high success rate ranging from $80 \%$ to $95 \%$ in more than 5 years of follow-up [2-5]. However, as many as $5-20 \%$ of patients experience failed sling treatment. Recently, several possible salvage options have been published, including pelvic floor rehabilitation, placement of an artificial urethral sphincter [6, 7], periurethral injection of bulking agents [7], colposuspension [8, 9], readjustment ( placation, shortening, or retensioning) of previously implanted tape [10-13], and a repeat MUS procedure ( TVT/TVT-O/TOT) [14-22]. The MUS procedure has been reported to be successful in treating recurrent/persistent SUI no matter which type of procedure had failed previously.

SUI failure after any prior sling procedure is defined as persistent SUI (leakage within 6 weeks of a previous MUS procedure) and recurrent SUI (leakage more than 6 weeks after initial success of first MUS) [17]. The etiology of persistent or recurrent SUI after surgery is unclear, but it may be related to improper adjustment of the tape intraoperatively, failure to fix the sling into place, or incorrect diagnosis of the form of incontinence $[15,16,20]$. Palva and Nilssion [21] grouped the reasons for a failed MUS procedure as follows: inadequate tape material, inadequate surgical technique, patient's medical condition, and unrecognized reasons. The mechanisms of the continence action 
of the MUS procedure (TVT/TVT-O) are the same, based on the integral theory by Ulmsten in 1993 [1]. A retropubic midurethral sling, also called TVT, was first introduced by Ulmsten. TVT acted as the pubourethral ligament (PUL) at an acute angle which provided continence by urethral kinking when coughing. Transobturator sling procedures, such as TOT described by Delorme [4] and TVT-O described by de Leval [5], also mimic the PUL but at less of an angle, acting as a hammock to provide continence by intermittent compression on the midurethra during increasing intra-abdominal pressure, consistent with the De Lancey theory [23].

\section{Methods}

We conducted combined or separate searches with the keywords: "TVT," "failure," "repeat TVT," and "recurrent/ persistent SUI" and reviewed the published literature solely on repeat MUS procedures to treat patients with failed prior MUS procedures. Medline and Science Citation Index databases were searched on PubMed to identify articles published between 2000 and 2010. Searches were also limited to humans, female patients, and English evidencebased papers.

Articles were focused on prior MUS procedure failure (TVT, TVT-O, TOT, and IVS) then treatment with a repeat MUS procedure. Primary references were also searched for secondary references.

Eight evidence-based research papers met our search criteria, two case reports $[10,20]$, and five original articles [14-17, 21, 22]. Clinical characteristics of the reviewed papers are summarized in the Table 1. Previous surgery indicated a first or multiple MUS procedures for SUI, which may have been combined with pelvic reconstructive surgery. Repeat surgery indicated repeat MUS using TVT, TVT-O, or TOT to treat recurrent or persistent SUI. Repeat MUS procedures in the reviewed papers could be combined with pelvic reconstructive surgery.

\section{Findings}

TVT has been shown to have excellent cure rates for SUI caused by urethral hypermobility (UH), intrinsic sphincter deficiency (ISD), and recurrent incontinence after retropubic urethropexy [24-26]. TVT-O/TOT has also shown excellent cure rates for SUI caused by UH and recurrent incontinence after retropubic urethropexy. These procedures have been performed for more than 20 years, with reported success rates over $90 \%$ in long-term follow-up. Various salvage methods have also shown good outcomes for MUS failure. However, there are limitations in papers reporting on repeat MUS (TVT, TVT-O, or TOT) after a prior MUS failure. It might be interesting to understand how repeat MUS (TVT/TVT-O/TOT) can be used to treat prior MUS failure. It really does not add anything to the paper and should not be used in the "Findings" paragraph. It would be better in the "Background" paragraph. Since you already stated the purpose of this paper several times, you really do not need the sentence.

Moore et al. [15] reported five patients with a diagnosis of SUI caused both by ISD (maximum urethral closure pressure $<20 \mathrm{cmH}_{2} \mathrm{O}$ and Valsalva leak point $<65 \mathrm{cmH}_{2} \mathrm{O}$ ) and UH (cotton swab test $>30^{\circ}$ ). Their five patients had persistent SUI after a primary TOT procedure. Postopertively, all patients with urodynamic testing still showed evidence of ISD and were treated successfully with repeat TVT without removal of the TOT sling from the prior procedure. Moore et al. [15] reported just five patients and concluded the TOT sling did not provide a large enough angle of support or enough urethral kinking to provide continence in patients with ISD. Therefore, a TVT sling was a viable option for a prior failed TOT [14]. Villet et el. [10] reported three patients with recurrent or persistent SUI after a prior TVT procedure. The position of the mesh from the first procedure was very loose in one patient, was not identified in a second patient, and was in a relatively good position and state of tension in the third patient. Tsivian et al. [16] reported that failures in 12 MUS procedures (TVT 9 cases, TOT 1 case, and IVS 2 cases) were at least in part because of a technical error (tape position too loose). They also reported that the problem of how tightly the sling should be placed beneath the urethra remained unresolved. This continues to be the long-standing "Achilles heel" of anti-incontinence surgery [16]. Paick et al. [11] reported two cases of recurrent incontinence treated by shortening the tape with clamp application, which may have indicated that loose tape caused the TVT failure.

The proper intervention and management of MUS failure has varied for patients with persistent and recurrent SUI. Preoperative evaluation has included a comprehensive medical history, physical examination (e.g., stress test, Bonney and Q-tip test), neurological evaluation, urinalysis, urine culture, pad test, uroflowmetry, post-void residual urine measurement, voiding diary and complete urodynamic study, and even a cystoscopic examination [14-17]. Before a repeat MUS procedure, conservative treatment, such as pelvic floor exercises or periurethral collagen injections and tape readjustment, was provided in some studies [13-16]. Moore et al. [15] provided the option of pelvic floor exercises and collagen injections, but patients eventually returned to a repeat TVT surgical intervention when they had no improvement. Tsivian et al. [16] reported a patient with unsuccessful TOT tape readjustment (plication) who was treated successfully by a second TOT 
Table 1 Characteristics of the reviewed researches

\begin{tabular}{|c|c|c|c|c|c|c|c|}
\hline Study & $\begin{array}{l}\text { Sample } \\
(n)\end{array}$ & $\begin{array}{l}\text { Age (years) } \\
\text { or mean, } \\
\text { and range } \\
\text { or SD }\end{array}$ & Prior surgery & $\begin{array}{l}\text { Repeat } \\
\text { surgery }\end{array}$ & $\begin{array}{l}\text { Time to repeat } \\
\text { surgery (months) } \\
\text { or mean, and } \\
\text { range or SD }\end{array}$ & $\begin{array}{l}\text { UD finding before } \\
\text { repeat surgery }\end{array}$ & Outcomes/conclusions \\
\hline \multirow[t]{2}{*}{$\begin{array}{l}\text { Riachi et } \\
\text { al. [19] }\end{array}$} & \multirow[t]{2}{*}{2} & 64 & $\begin{array}{l}\text { MMK urethropexy, } \\
\text { allograft fascial } \\
\text { sling, TVT }\end{array}$ & $\begin{array}{l}\text { TVT (previous } \\
\text { TVT tape was } \\
\text { not identified) }\end{array}$ & 8 & $\begin{array}{l}\text { Q-tip }=40^{\circ}, \text { UD } \\
\text { confirmed SUI }\end{array}$ & $\begin{array}{l}\text { Remained continence on } \\
\text { 13-month follow-up }\end{array}$ \\
\hline & & 71 & $\begin{array}{l}\text { Autologous fascial } \\
\text { sling, TVT }\end{array}$ & $\begin{array}{l}\text { TVT (previous } \\
\text { TVT tape was } \\
\text { found) }\end{array}$ & 9 & $\begin{array}{l}\text { UD confirmed SUI } \\
\text { with ISD }\end{array}$ & $\begin{array}{l}\text { SUI completely resolved on } \\
\text { 6-month follow-up }\end{array}$ \\
\hline \multirow[t]{2}{*}{$\begin{array}{l}\text { Villet et } \\
\text { al. [10] }\end{array}$} & \multirow[t]{2}{*}{2 of 3} & 54 & TVT & $\begin{array}{l}\text { TVT(previous TVT } \\
\text { was not identified) }\end{array}$ & 18 & $\begin{array}{l}\text { Patient gained } 6 \mathrm{~kg} \text {; } \\
\text { positive stress test } \\
\text { with urethral } \\
\text { hypermobility }\end{array}$ & $\begin{array}{l}\text { At } 12 \text { months follow-up, the } \\
\text { patient is still continent }\end{array}$ \\
\hline & & 73 & $\begin{array}{l}\text { Burch colpopexy, } \\
\text { TVT }\end{array}$ & $\begin{array}{l}\text { TVT (previous TVT } \\
\text { tape was found) }\end{array}$ & 8 & $\begin{array}{l}\text { No mention may be } \\
\text { due to persistent SUI }\end{array}$ & $\begin{array}{l}\text { At } 4 \text { months follow-up, the } \\
\text { patient is continent }\end{array}$ \\
\hline $\begin{array}{l}\text { Eandi et } \\
\text { al. [13] }\end{array}$ & 10 & $\begin{array}{l}65.1 \text { (range } \\
43-80)\end{array}$ & $\begin{array}{l}\text { TVT } 5 \text { cases, TOT } \\
5 \text { cases }\end{array}$ & All TVT & $14(3-32)$ & $\begin{array}{l}\text { VLPP }\left(\mathrm{cmH}_{2} \mathrm{O}\right) \\
<60,3 \text { cases } \\
60-100,4 \text { cases } \\
>100,3 \text { cases }\end{array}$ & $\begin{array}{l}\text { Follow-up at a mean of } 16 \\
\text { months (range } 6-33) ; 7 \\
\text { patients ( } 70 \% \text { ) reported } \\
\text { complete or improved } \\
\text { continence and quality } \\
\text { of life, } 3 \text { patients failed; } \\
\text { second TVT may be a } \\
\text { viable option after failure } \\
\text { of initial MUS procedure }\end{array}$ \\
\hline $\begin{array}{l}\text { Moore et } \\
\text { al. [14] }\end{array}$ & 5 & $\begin{array}{l}66.3 \text { (range } \\
56-76)\end{array}$ & $\begin{array}{l}\text { TOT (initial TOT in } \\
4 \text { cases, and } 1 \text { with } \\
\text { h/o failed Burch, } \\
\text { combined pelvic } \\
\text { reconstruction in } \\
4 \text { cases) }\end{array}$ & All TVT & $3(1-7)$ & $\begin{array}{l}\text { Diagnosis of ISD for } \\
5 \text { patients (ISD, MUCP } \\
<20 \mathrm{cmH}_{2} \mathrm{O} \text { or VLPP } \\
<65 \mathrm{cmH}_{2} \mathrm{O} \text { ) }\end{array}$ & $\begin{array}{l}\text { All five patients successfully } \\
\text { treated with repeat TVT; } \\
\text { TVT may be more } \\
\text { appropriate treating patients } \\
\text { with ISD because TVT } \\
\text { offered more acute retropubic } \\
\text { angle }\end{array}$ \\
\hline $\begin{array}{l}\text { Tsivian et } \\
\text { al. [15] }\end{array}$ & 12 & $\begin{array}{l}64.3 \text { (range } \\
47-80)\end{array}$ & $\begin{array}{l}\text { TVT } 9, \text { TOT } 1, \\
\text { IVS } 2\end{array}$ & $\begin{array}{l}\text { TVT } 5 \text {, TOT } 3, \\
\text { IVS } 4\end{array}$ & $21.4(1-48)$ & $\begin{array}{l}4 \text { cases of VLPP } \\
<60 \mathrm{cmH}_{2} \mathrm{O}, 8 \text { cases } \\
\text { of mobile urethra }\end{array}$ & $\begin{array}{l}11 \text { patients }(91.7 \%) \text { achieved } \\
\text { continence after repeat MUS } \\
\text { (mean follow-up of } 23.2 \text {, } \\
\text { range } 14-44 \text { ); the choice of } \\
\text { MUS procedure is a matter } \\
\text { of surgeon's preference; the } \\
\text { timing of repeat MUS is no } \\
\text { delay }\end{array}$ \\
\hline $\begin{array}{l}\text { Lee et al. } \\
\quad[16]\end{array}$ & 29 & $\begin{array}{l}54.1 \pm 10.8 \\
\quad(\mathrm{SD})\end{array}$ & $\begin{array}{l}\text { Retropubic route- } \\
\text { TVT } 17 \\
\text { Transobturator } \\
\text { route-TOT } 6 \text {, } \\
\text { TVT-O } 6\end{array}$ & $\begin{array}{l}\text { Retropubic route- } \\
\text { TVT } 13 \\
\text { Transobturator } \\
\text { route-TOT } 8 \\
\text { TVT-O } 8\end{array}$ & $20.0 \pm 16.9$ & $\begin{array}{l}\text { In patients with UD } \\
\text { examination, increased } \\
\text { VLPP (mean } \pm \mathrm{SD} \text {, } \\
\left.55.4 \pm 22.6 \mathrm{cmH}_{2} \mathrm{O}\right) \\
\text { after initial MUS } \\
\text { procedure }(35.6 \pm 12.9)\end{array}$ & $\begin{array}{l}\text { Total cure rates: } 22 / 29(75.9 \%) \\
\text { at mean follow-up of } \\
13 \text { months; cure rates: } \\
\text { retropubic }(12 / 13,92.3 \%) \text { vs. } \\
\text { transobturator }(10 / 16,62.5 \%) \\
\text { with } p=0.0089 ; \text { transobturator } \\
\text { approach: TVT-O }(6 / 8,75 \%) \\
\text { vs. TOT }(4 / 8,50 \%) \text { with } \\
\text { significant } p=0.048\end{array}$ \\
\hline $\begin{array}{l}\text { Palva and } \\
\text { Nilsson [20] }\end{array}$ & 20 & $61 \pm 9(\mathrm{SD})$ & $\begin{array}{l}\text { All TVT (tape } \\
\text { material-Teflon } \\
\text { 3, Mersilene 5, } \\
\text { polypropylene 13) }\end{array}$ & $\begin{array}{l}\text { All TVT (Gynecare, } \\
\text { J\&J) }\end{array}$ & $57 \pm 32$ & $\begin{array}{l}\text { Stress test }(-) \text { in } 15 \\
\text { patients, pad test was } \\
\text { negative in } 13 \text { patients; } \\
\text { both stress and pad test } \\
(-) \text { in } 11 \text { patients }\end{array}$ & $\begin{array}{l}5 \text { years follow-up of repeat TVT } \\
\text { revealed a } 75 \%(15 / 20) \text { objective } \\
\text { cure or improvement rate; } \\
\text { inadequate tape material, } \\
\text { inadequate surgical technique, } \\
\text { patients' medical condition, and } \\
\text { unrecognized reasons may cause } \\
\text { the failed primary TVT }\end{array}$ \\
\hline $\begin{array}{l}\text { Van Baelen and } \\
\text { Delaere [22] }\end{array}$ & 21 & $\begin{array}{r}56 \text { (range } \\
33-77 \text { ) }\end{array}$ & TVT 5, TOT 16 & All TOT & 18 & $\begin{array}{l}\text { Urodynamic study } \\
\text { performed, but no } \\
\text { mention of the report }\end{array}$ & $\begin{array}{l}\text { Failure rate was } 30 \% \text { in repeat } \\
\text { TOT surgery; the transobturator } \\
\text { approach seems to show poorer } \\
\text { outcomes than the retropubic } \\
\text { approach in repeat sling surgery }\end{array}$ \\
\hline
\end{tabular}

$M M K$ Marshall-Marchetti-Krantz urethropexy, UD urodynamic study, VLPP Valsalva leak point pressure, ISD intrinsic sphincter deficiency, $M U C P$ maximum urethral closure pressure, MUS midurethral sling, TVT tension-free vaginal tape, TOT transobturator tape, IVS intravaginal slingplasty 
intervention. Riachi et al. [20] reported two patients treated by a repeat TVT sling. The tape from the previous procedure was not identified in one patient, but in the other, the mesh was partially visualized in a good position and was not removed. The management and the findings were the same as in Villet's study [10]. Tsivian et al. [16] suggested adjustment of the tape from a prior procedure if it is in good condition and a good location. However, in view of their limited experience with readjustment, they currently prefer a repeat MUS procedure. The choice of procedure (TVT, TVT-O/TOT, or IVS) is the surgeon's preference, and surgery need not be delayed unless there is local inflammation [16].

A repeat TVT sling for the treatment of a failed primary TVT was first reported by Riachi et al. [20]. Since then, a case series study and small population outcome studies have been reported worldwide with success rates of 70 $92 \%$ for a repeat tape procedure [14-17, 21, 22]. In a larger study at two Korean centers [17], 29 of 31 female patients with a repeat MUS, 13 with TVT and 16 with TVT-O/TOT, were followed. The cure and improvement rates were $75.9 \%$ (22/29 patients) and 6.9\% (2/29), respectively. The cure rates in the repeat retropubic vs. transobturator route were $92.3 \%$ (12/13 patients) vs. $62.5 \%$ (10/16 patients) with a $p$ value of $0.089(>0.05)$, although the rate for the retropubic route was higher than that of the transobturator route. Moreover, they found out that in the repeat transobturator route $(n=16)$, TVT-O $(75 \%, 6 / 8$ patients) were more effective than TOT ( $50 \%, 4 / 8$ patients) with a $p$ value of 0.048. Van Baelen and Delaere [22] reported 21 patients (prior failed TVT, 5 cases and TOT, 16 cases) with a success rate of $70 \%$ for a repeat TOT procedure and concluded that the transobturator approach had poorer outcomes than the retropubic approach in repeat sling surgery.

In the reviewed studies, a repeat TVT procedure for prior TVT failure showed success rates ranging from $70 \%$ to $90 \%$. The outcomes were not significantly different between a repeat retropubic route (TVT) or transobturator route (TVT-O/TOT). A repeat MUS procedure for persistent or recurrent stress urinary incontinence is a reliable option for patients with prior MUS failure.

\section{Conclusions}

The cure rates for treating recurrent or persistent SUI after a repeat MUS show good outcomes, proving this is a viable procedure. The choice of repeat MUS procedure might depend on the type of SUI determined after a thorough preoperative examination. The retropubic sling might be better than the transobturator approach in repeat MUS surgery. Meanwhile, there is no need to delay repeat TVT for patients with a prior failed MUS, and it is unnecessary to identify and remove the tape used in previous procedures.

Declaration of interest The authors report no conflicts of interest. The authors alone are responsible for the content and writing of the paper.

\section{References}

1. Ulmsten U, Henriksson L, Johnson P, Varhos G (1996) An ambulatory surgical procedure under local anesthesia for treatment of female urinary incontinence. Int Urogynecol J Pelvic Floor Dysfunct 7:81-86

2. Doo CK, Hong B, Chung BJ et al (2006) Five-year outcomes of the tension-free vaginal tape procedure for treatment of female stress urinary incontinence. Eur Urol 50:333-338

3. Nilsson CG, Falconer C, Rezapour M (2004) Seven-year followup of the tension-free vaginal tape procedure for treatment of urinary incontinence. Obstet Gynecol 104:1259-1262

4. Delorme E (2001) Transobturator urethral suspension: miniinvasive procedure in the treatment of stress urinary incontinence in women. Prog Urol 11:1306-1313

5. de Leval J (2003) Novel surgical technique for the treatment of female stress urinary incontinence: transobturator vaginal tape inside-out. Eur Urol 44:724-730

6. Elliott DS, Barrett DM (1998) The artificial urinary sphincter in the female: indications for use, surgical approach and results. Int Urogynecol J Pelvic Floor Dysfunct 9:409-415

7. Schulz JA, Drutz HP (1999) The surgical management of recurrent stress urinary incontinence. Curr Opin Obstet Gynecol 11:489-494

8. Nitahara KS, Aboseif S, Tanagho EA (1999) Long-term results of colpocystourethropexy for persistent or recurrent stress urinary incontinence. J Urol 162:138-141

9. Amaye-Obu FA, Drutz HP (1999) Surgical management of recurrent stress urinary incontinence: a 12-year experience. Am J Obstet Gynecol 181:1296-1307

10. Villet R, Ercoli A, Atallah D, Hoffmann P, Salet-Lizee D (2002) Second tension-free vaginal tape procedure and mesh retensioning: two possibilities of treatment of recurrent-persistent genuine stress urinary incontinence after a primary tension-free vaginal tape procedure. Int Urogynecol J Pelvic Floor Dysfunct 13:377379

11. Paick JS, Ku JH, Shin JW, Park KJ, Kim SW, Oh SJ (2004) Shortening of tension-free vaginal tape for the treatment of recurrent incontinence. J Urol 171:1634

12. Lo TS, Wang AC, Liang CC, Long CY, Lee SJ (2006) Treatment for unsuccessful tension-free vaginal tape operation by shortening pre-implanted tape. J Urol 175:2196-2200

13. de Landsheere L, Lucot JP, Foidart JM, Cosson M (2010) Management of recurrent or persistent stress urinary incontinence after TVT-O by mesh readjustment. Int Urogynecol J Pelvic Floor Dysfunct 21:1347-1351

14. Eandi JA, Tanaka ST, Hellenthal NJ, O'Connor RC, Stone AR (2008) Self-reported urinary continence outcomes for repeat midurethral synthetic sling placement. Int Braz J Urol 34:336-344

15. Moore RD, Gamble K, Miklos JR (2007) Tension-free vaginal tape sling for recurrent stress incontinence after transobturator tape sling failure. Int Urogynecol J Pelvic Floor Dysfunct 18:309313 
16. Tsivian A, Neuman M, Yulish E et al (2007) Redo midurethral synthetic sling for female stress urinary incontinence. Int Urogynecol J Pelvic Floor Dysfunct 18:23-26

17. Lee KS, Doo CK, Han DH, Jung BJ, Han JY, Choo MS (2007) Outcomes following repeat mid urethral synthetic sling after failure of the initial sling procedure: rediscovery of the tension-free vaginal tape procedure. J Urol 178(4 Pt 1):13701374

18. Scarpero HM, Dmochowski RR (2004) Sling failures: what's next? Curr Urol Rep 5:389-396

19. Lo TS, Horng SG, Chang CL, Huang HJ, Tseng LH, Liang CC (2002) Tension-free vaginal tape procedure after previous failure in incontinence surgery. Urology 60:57-61

20. Riachi L, Kohli N, Miklos J (2002) Repeat tension-free transvaginal tape (TVT) sling for the treatment of recurrent stress urinary incontinence. Int Urogynecol J Pelvic Floor Dysfunct 13:133-135

21. Palva K, Nilsson CG (2009) Effectiveness of the TVT procedure as a repeat mid-urethra operation for treatment of stress incontinence. Int Urogynecol J Pelvic Floor Dysfunct 20:769-774

22. Van Baelen AA, Delaere KP (2009) Repeat transobturator tape after failed mid-urethral sling procedure: follow-up with questionnaire-based assessment. Urol Int 83:399-403

23. DeLancey JO (1994) Structural support of the urethra as it relates to stress urinary incontinence: the hammock hypothesis. Am J Obstet Gynecol 170:1713-1723

24. Palma PC, Riccetto CL, Dambros M (2002) Tension-free vaginal tape (TVT): minimally invasive technique for stress urinary incontinence (SUI). Int Braz J Urol 28:458-463

25. Rardin CR, Kohli N, Rosenblatt PL, Miklos JR, Moore RD, Strohsnitter WC (2002) Tension-free vaginal tape: outcomes among women with primary versus recurrent stress urinary incontinence. Obstet Gynecol 100(5 Pt 1):893-897

26. Rezapour M, Falconer C, Ulmsten U (2001) Tension-free vaginal tape (TVT) in stress incontinent women with intrinsic sphincter deficiency (ISD) - a long-term follow-up. Int Urogynecol J Pelvic Floor Dysfunct 12(Suppl 2):S12-S14 